\title{
NUMERICAL MODEL OF THE CATCHMENTS OF THE OZIĄBEL AND WOŁCZYŃSKI STRUMIEŃ RIVERS - WOŁCZYN MUNICIPALITY
}

\author{
TOMasz OlichWer, Marek WCisło, Stanisław Staśko, \\ SEBAstian BuczyŃSKi, Magdalena MODELSKa, Robert TARKa \\ Institute of Geological Sciences, University of Wrocław, pl. Maksa Borna 9, 50-204 Wrocław \\ tomasz.olichwer@ing.uni.wroc.pl, marek.wcislo@ing.uni.wroc.pl, \\ stanislaw.stasko@ing.uni.wroc.pl, sebastian.buczynski@ing.uni.wroc.pl, \\ magdalena.modelska@ing.uni.wroc.pl, robert.tarka@ing.uni.wroc.pl
}

\begin{abstract}
The article presents a numerical model designed for determining groundwater dynamics and water balance of the catchments of the Oziąbel (Czarna Woda) river and the Wołczyński Strumien river in Wołczyn region. Hydrogeological mapping and modelling research covered the area of $238.9 \mathrm{~km}^{2}$. As a result of measurements performed in 2008-2009, flows were determined in major rivers and water table positions were measured at 26 points. In the major part of the area described, the water table, lying at the depth of 1.5-18.7 m, has unconfined character, and the aquifer is built of Neogene (Quaternary) sands and gravels. In the area under study, groundwaters are drawn from 6 wells with total withdrawal of $6133 \mathrm{~m}^{3} / \mathrm{d}$. The numerical modelling was performed with the use of Visual Modflow 3.1.0 software. The area was partitioned by a discretization grid with a step size $l=250 \mathrm{~m}$. The conceptual model of the hydrogeological system is based on hydrological data gathered over a period of one year, data from HYDRO bank database, cross-sections and maps. The boundaries of the modelled hydrogeological system were established on the watersheds of the Wołczyński Strumien river and the Oziąbel river, apart from the areas where they run together. The modelled area was extended $\left(271.5 \mathrm{~km}^{2}\right)$ around the Wołczyński Strumień river catchment to achieve a more effective mapping of the anthropogenic impact on its balance and the hydrodynamic system of the catchment area. The structure is characterised by the occurrence of one or rarely two aquifers separated by a pack of Quaternary clays. The investigation produced a detailed water balance and its components.
\end{abstract}

\section{INTRODUCTION}

The aim of the article is to present the results of numerical modelling of the Oziąbel (Czarna Woda) and the Wołczyński Strumien river basins in the area of Wołczyn municipality (Opole province).

The numerical model was designed with the use of Visual ModFlow Version 3.1.0 software, one of the most popular software packs used for modelling groundwater flow in pore systems. The software is based on solving hydraulic head distribution by means of a differential filtration equation, based on finite difference method (FDM). The filtration field is discretized with a grid of rectangular blocks defined by a system of rows and columns (Gurwin and Poprawski [4], Anderson and Woessner [1]).

When building a model of the Wołczyński Strumien river and the Oziąbel river catchment area, the researchers tried to obtain such values of hydrogeological pa- 
rameters for which the model would reflect the actual distribution of hydraulic heads, values of groundwater runoff recorded by surface waters, and possibly the most reliable circulation system and groundwater balance. The accordance obtained would make it possible to consider the model appropriate for research based on simulation of groundwater balances and resources, and, consequently, for protecting them. The hydrogeological system chosen for modelling research (Fig. 1) is characterised by relatively uncomplicated hydrogeological conditions, generally due to containing one pore aquifer with a supra-clay horizon occurring locally in its central section.

\section{AREA UNDER STUDY}

The study area of $238.9 \mathrm{~km}^{2}$ consists of the catchments of the Oziąbel river $\left(101.1 \mathrm{~km}^{2}\right)$ and the Wołczyński Strumień river $\left(137.8 \mathrm{~km}^{2}\right)$ in Wołczyn municipality in Opole province (Fig. 1).

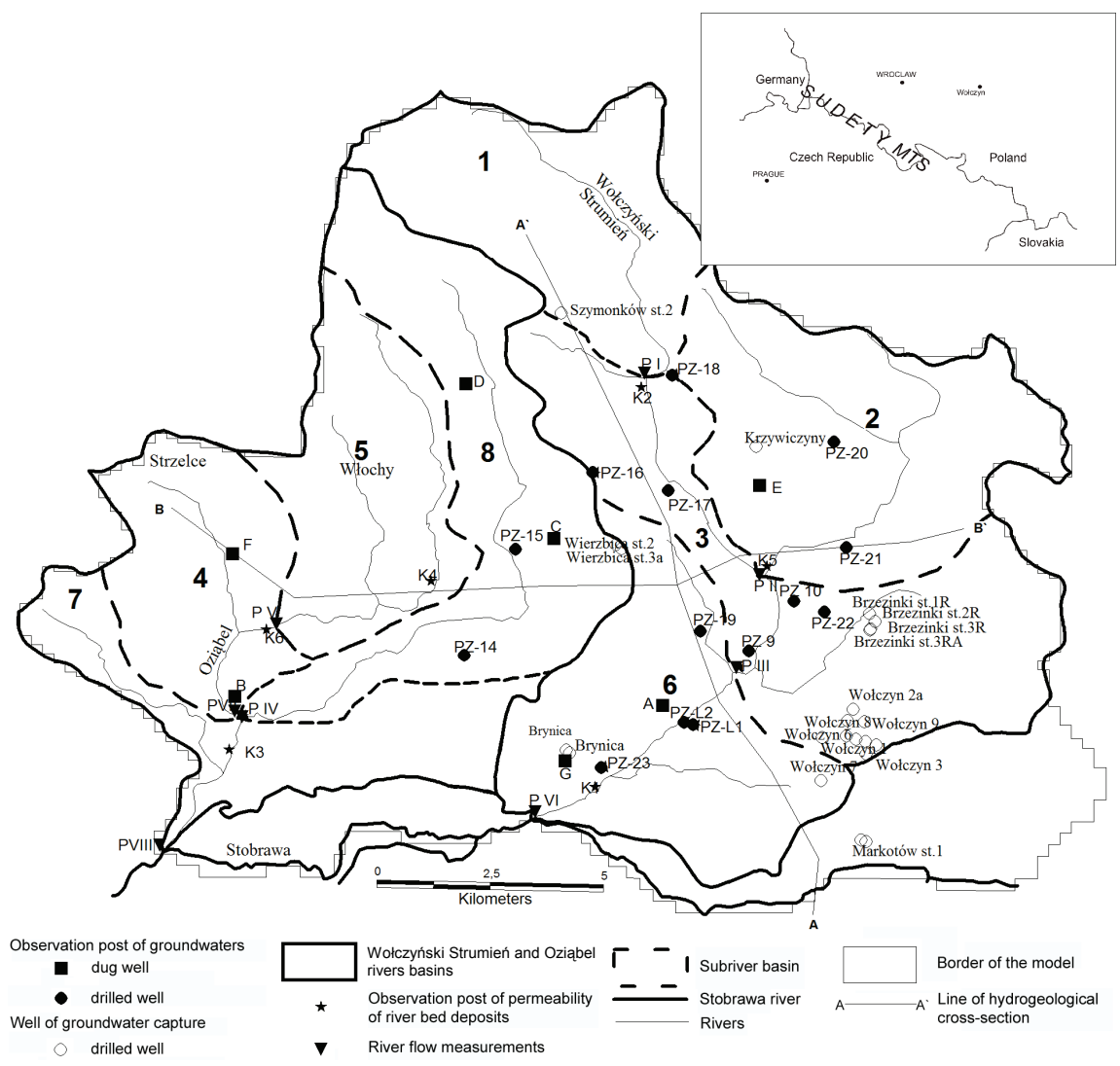

Fig. 1. Documentation map of the study area 
The area is situated in the Fore-Sudetic monocline. The bedrock in this area contains Triassic formations, represented by Rhaetian and Keuper sediments, which developed as variegated clays and claystones with limestones, sandstones, shales and siltstones. The Triassic formation is covered by $20-40 \mathrm{~m}$ thick Cainozoic sediments and its top, quite uniform morphologically, lies at the elevation of 140-160 m above mean sea level. Paleogene formations are about a dozen meters thick. They are composed of green, blue and variegated clays (Poznań series) and usually overlie Rhaetian clays (Górnik [5]). Neogene (Quaternary) formations occur all over the area under study, and their thickness depends on the surface features of the sub-Quaternary bedrock and terrain morphology. Data from older boreholes indicate that their thickness ranges from $9.3 \mathrm{~m}$ to almost $30 \mathrm{~m}$ (Dąbrowski [2]).

It is common that groundwaters inside hydrographic basin areas, in regional perspective, form a multi-layer groundwater aquifer system in Cainozoic and Mesozoic formations connected with surface waters through their circulation system. In the areas described, one can identify a piece of Olesno-Kluczbork-Wołczyn-Namysłów buried valley. This valley was formed in Keuper shales and it is filled with sand-gravel formations. Inside the Quaternary formations, two aquifers have been identified. The top (first) horizon, related to sand-gravel formations of fluvial, water-glacial and glacial origin, occurs almost all over the area. The presence of the second aquifer is limited to the area of the buried valley, and it is built of gravel-sand sediments underlying the bottom horizon of moraine clays. The Quaternary water-bearing horizon is hydraulically separated from the underlying Triassic horizon by Keuper shales (Dziedziak [3]). In most of the area described, water table has unconfined character and it lies at the depth of $1.5 \mathrm{~m}$ to $18.7 \mathrm{~m}$ (Fig. 2). The presence of confined groundwaters has local character and is related to the occurrence of patches of moraine clays inside sand formations. Hydraulic conductivity inside the Quaternary water-bearing horizon varies from $1.12 \cdot 10^{-4}$ to $4.14 \cdot 10^{-4} \mathrm{~m} / \mathrm{s}$ for aquifer thickness range of 4.5-31.9 $\mathrm{m}$ (Górnik [5]). The Tertiary aquifer occurs locally in the northern part of the area under study near Krzywiczyny and it is connected with deposits of sands and secondarily of brittle sandstones, with thickness of about a dozen metres (Górnik [5]). This water-bearing horizon has a confined water table, stabilized at the depth of about $8 \mathrm{~m} \mathrm{b.g.l.} \mathrm{The}$ hydraulic conductivity of the extracted aquifers reaches $6.3 \cdot 10^{-5} \mathrm{~m} / \mathrm{s}$. The clay layer separates the Tertiary aquifer from the water-bearing horizons above it. The Triassic aquifer is represented by Rhaetian rocks. The water-bearing character of this horizon is related to the occurrence of sandy inserts inside Upper Triassic formations. The transmissivity of this aquifer is below $1.15 \cdot 10^{-3} \mathrm{~m}^{2} / \mathrm{s}$. This level has a confined water table, stabilized at the depth of $2 \mathrm{~m}$ b.g.l. (Górnik [5]). Groundwaters are recharged through infiltration of precipitation and inflows from higherlying areas. 
An additional element that can influence the shape of groundwater resources in the area under study is agricultural waste used by Yeast Factory Lesaffre Polska S.A. in Wołczyn. The post-manufacturing waste is diluted with water and sprayed over farmland in the south-eastern part of the area described.

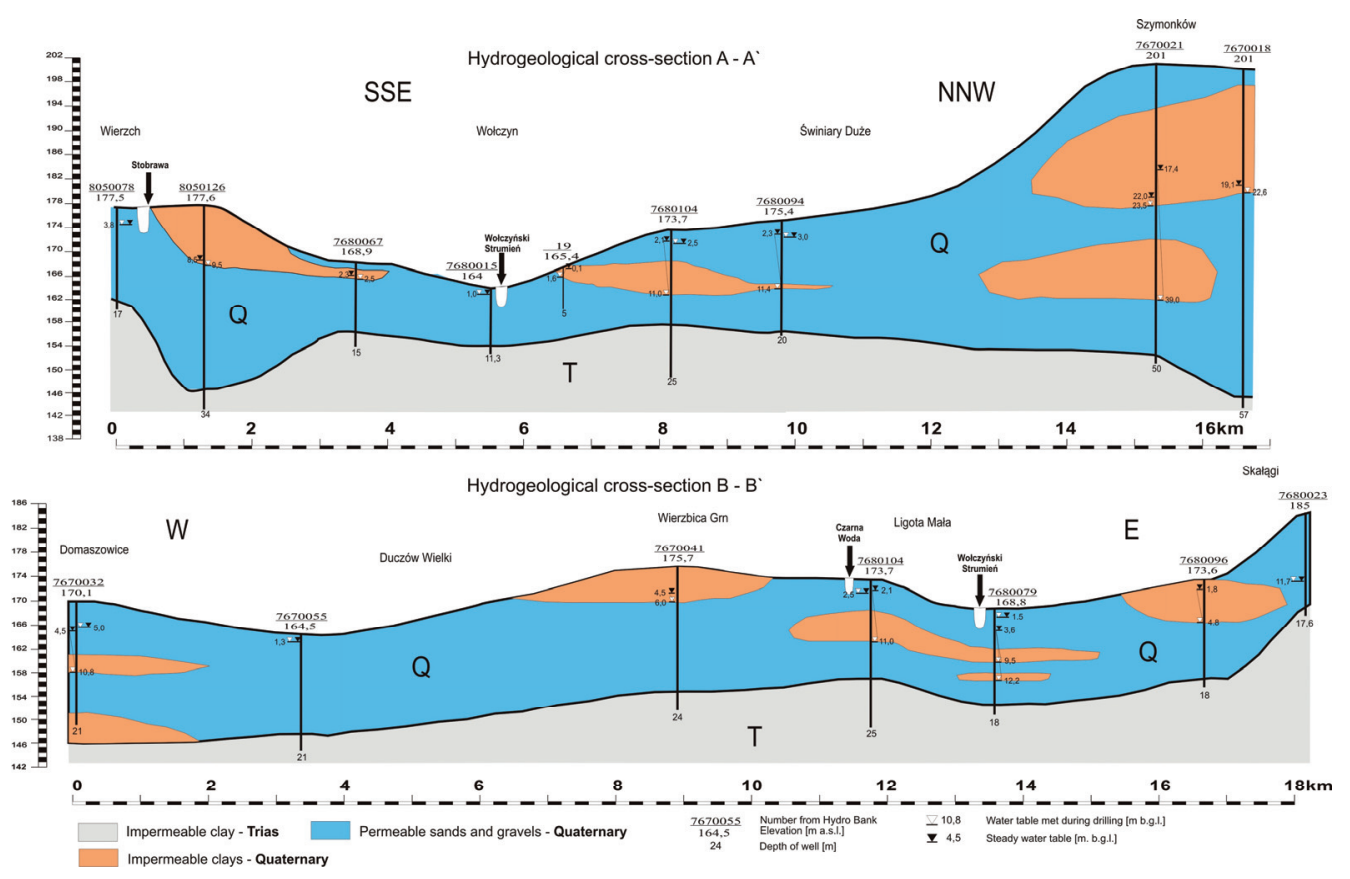

Fig. 2. Hydrogeological cross-sections through the study area

In the study area there are six working groundwater captures (Fig. 1) in Brzezinki, Markotów, Szymonków, Wierzbica, Krzywiczyny and Wołczyn. At the end of 2008, a well in Brynica was closed due to the bad quality of water. The data from 20082009 list the following monthly withdrawals: Brzezinki $41000 \mathrm{~m}^{3} / \mathrm{month}$, Markotów $1200 \mathrm{~m}^{3} /$ month, Szymonów $2100 \mathrm{~m}^{3} /$ month, Wierzbica $9500 \mathrm{~m}^{3} /$ month, Krzywiczyny $2700 \mathrm{~m}^{3} /$ month, Wołczyn $160000 \mathrm{~m}^{3} /$ month. In the area of Wołczyn there is also an unused surface capture, intended for manufacturing needs of the yeast factory "Lesaffre Polska".

\section{FIELD WORKS}

Solving the problem of creating a numerical model required performing chamber and field measurements, which were conducted in 2008-2009. Water table depth data 
from 26 observation sites were used (PZ-0, PZ-00, PZ-1, PZ-2, PZ-3, PZ-4, PZ-5, PZ-6, PZ-7, PZ-8, PZ-9, PZ-10, PZ-11, PZ-13, PZ-14, PZ-15, PZ-16, PZ-17, PZ-18, PZ-19, PZ-20, PZ-21, PZ-22, PZ-23, PZ-L1, PZ-L2, (Fig. 1)).

Hydrogeological mapping covered the area of $238.9 \mathrm{~km}^{2}$. To perform this task, measurements and investigation were performed on 5 drilled wells, where water table depths were measured. Moreover, hydrogeological mapping included: checking the current state and values of groundwater withdrawal from wells in groundwater captures, measuring the depths of dynamic and static water tables, and choosing well No. 1 at Brynica groundwater capture for continuous measurement of changes in groundwater table position.

In the six selected dug wells (A, B, C, D, E and F), water table depths and well depths were measured and water table position measurements were performed in seven series. Eight permanent hydrometric cross-sections were located on the Wolczyński Strumień, Oziąbel rivers and their tributaries. Eight river sub-catchments were delineated (Fig. 1) to enable an in-depth analysis of hydrologic characteristics of the area. Flow measurements were conducted in cross-sections closing selected small river sub-basins. Measurements were conducted in 7 series, including those in low-water periods, in order to determine the value of groundwater runoff. Moreover, at the mouth cross-sections of the Wołczyński Strumień (PVI) and the Oziąbel river basins (PVIII), devices for continuous recording of water flows in the watercourses were installed. Additionally, the conductance of river-bed deposits was measured at 6 points in the two main rivers. Flow changes are shown in Fig. 3. Groundwater runoff was determined based on graphical baseflow separation method.

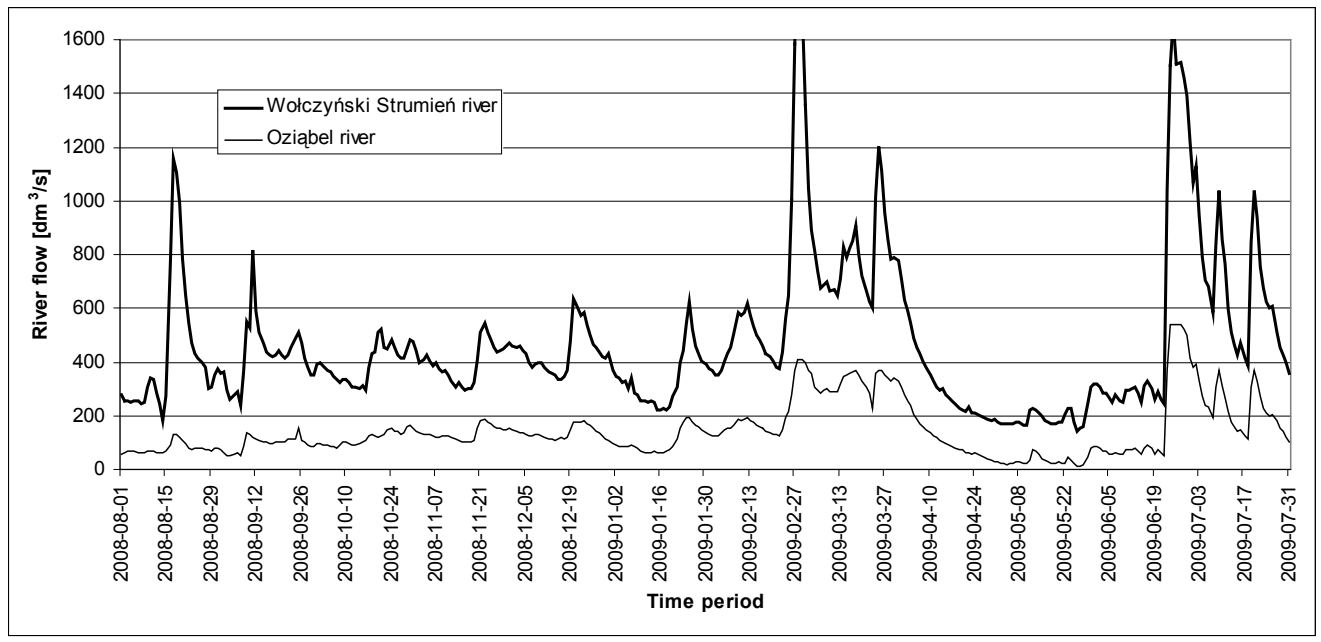

Fig. 3. River flow $\left(\mathrm{dm}^{3} / \mathrm{s}\right)$ in the Oziąbel and the Wołczyński Strumien rivers between 1.08.2008 and 31.07.2009 


\section{NUMERICAL MODEL}

Modelling studies were realized in Visual Modflow code - the most popular and fully verified software used by hydrogeologist. Visual Modflow is one of many graphical interfaces of Modflow available.

MODFLOW (McDonald and Harbaugh [7]) is the U.S. Geological Survey modular finite-difference flow model, which is a computer code that solves the groundwater flow equation

$$
\frac{\partial}{\partial x}\left[K_{x x} \frac{\partial h}{\partial x}\right]+\frac{\partial}{\partial_{y}}\left[K_{y y} \frac{\partial h}{\partial y}\right]+\frac{\partial}{\partial z}\left[K_{z z} \frac{\partial h}{\partial z}\right]+W=S_{s} \frac{\partial h}{\partial t}
$$

where:

$K_{x x}, K_{y y}, K_{z z} \quad-$ values of hydraulic conductivity along the $x, y$, and $z$ coordinate axes $(\mathrm{L} / \mathrm{T})$,

$h \quad-$ potentiometric head (L),

$W \quad-$ volumetric flux per unit volume representing sources and/or sinks of water, where negative values are extractions, and positive values are injections $(\mathrm{T}-1)$,

$S_{s} \quad-$ specific storage of the porous material $(\mathrm{L}-1)$, and

$t \quad-$ time $(\mathrm{T})$

The above finite difference form of Darcy's Law serves to simulate groundwater flow in porous media in continuous environment and is adequate.

The conceptual model of the hydrogeological system was based on data gathered during a year-long measurement period (1 August 2008-31 July 2009), data from HYDRO-bank database, cross-sections, maps and the other data presented in this article. The boundaries of the modelled hydrogeological system were established on the watersheds of the Wołczyński Strumien and the Oziąbel rivers (Fig. 1), apart from the areas where they run together. The model was slightly extended around the Wołczyński Strumień river catchment, which enabled a more effective mapping of the anthropogenic impact on its balance and the hydrodynamic system of the river basin area. The zone delineated in this way has the surface area $A=271.5 \mathrm{~km}^{2}$. The model is built of one or rarely two aquifers separated by a pack of Quaternary clays. Despite the local character of clay occurrence, it was decided that two Quaternary aquifers in the central part of the area would be considered - the supraclay (continuous all over the area) and sub-clay one (only in the centre of the area). The hydraulic conductivity ranges between $4 \cdot 10^{-5}$ and $10^{-3} \mathrm{~m} / \mathrm{s}$. The highest values were recorded in the western part of the Oziąbel river catchment area and near the Wołczyn town.

The water balance varies throughout the area discussed. In its western part (the Oziąbel river basin), it is shaped by natural factors. In the east (the Wołczyński Strumien river basin), it is influenced in many ways by human activity. Despite a well-developed water-and-waste management system in this region, the research has demonstrated that 
the natural balance is slightly disturbed by wastewater discharge from the municipal sewage treatment plant, discharge of waters drawn at the yeast factory capture, as well as withdrawal and discharge of surface waters. The latter component does not affect groundwater balance and it is somewhat a closed system in terms of balance. An additional recharging element is wastewater spray irrigation for agricultural use. These quantities are monitored by the yeast factory both in terms of time and space. On the other hand, it is difficult to estimate the amount of wastewater that finds its way to the groundwaters. This is due to the fact that spray irrigation is performed only during the plant growing season, (when evaporation is very high), and not at the time of the most intensive recharging of groundwater (early spring). It was decided that the element of the balance being discussed will be analysed in more detail trough numerical model calibration.

Within the river catchment area, groundwaters are withdrawn from groundwater captures for municipal and industrial purposes (Table 1). In 2008, the total groundwater extraction amounted to ca. $2.24 \mathrm{mln} \mathrm{m}^{3}$, which gives the mean withdrawal of $Q=6133 \mathrm{~m}^{3} / \mathrm{d}$.

Table 1

Groundwater captures incorporated in the model

\begin{tabular}{|c|l|c|c|c|c|c|c|}
\hline No. & \multicolumn{1}{|c|}{ Name } & No. RBDH & Elevation & x 1992 & y 1992 & Filter top & $\begin{array}{c}\text { Filter } \\
\text { bottom }\end{array}$ \\
\hline 1 & Brynica & 7670057 & 171.8 & 429500 & 349159 & 140.8 & 131.8 \\
\hline 2 & Szymonków st.2 & 7670021 & 201 & 429268 & 359232 & 159 & 153 \\
\hline 3 & Wierzbica st.2 & 7670040 & 175.5 & 430023 & 352889 & 159.5 & 155.5 \\
\hline 4 & Wierzbica st.3a & 7670042 & 175.3 & 430150 & 352866 & 158.8 & 154.3 \\
\hline 5 & Brynica & 7670051 & 172 & 429462 & 349222 & 141 & 134 \\
\hline 6 & Krzywiczyny & 7680061 & 188.5 & 432944 & 357091 & 167 & 160.5 \\
\hline 7 & Markotów st.1 & 8050051 & 177 & 436033 & 347190 & 150.5 & 145.5 \\
\hline 8 & Markotów st.2 & 8050126 & 177.6 & 435986 & 347218 & 154.6 & 146.6 \\
\hline 9 & Brzezinki st.1R & 7680120 & 169.4 & 436132 & 352250 & 153.4 & 143.4 \\
\hline 10 & Brzezinki st.2R & 7680118 & 169.4 & 436250 & 352080 & 154.4 & 144.4 \\
\hline 11 & Brzezinki st.3R & 7680106 & 172 & 436151 & 351916 & 158 & 148 \\
\hline 12 & Brzezinki st.3RA & 7680117 & 167.9 & 436137 & 351892 & 153.9 & 143.9 \\
\hline 13 & Wołczyn 1 & 7680004 & 178.4 & 435624 & 349550 & 160.4 & 148.4 \\
\hline 14 & Wołczyn 2 & 7680005 & 183.2 & 436047 & 349423 & 155.2 & 145.7 \\
\hline 15 & Wołczyn 3 & 7680007 & 190.8 & 436057 & 349141 & 154.3 & 146.3 \\
\hline 16 & Wołczyn 4 & 7680015 & 181.58 & 435836 & 349475 & 154.58 & 145.58 \\
\hline 17 & Wołczyn 6 & 7680072 & 171.28 & 435088 & 349508 & 151.13 & 144.13 \\
\hline 18 & Wołczyn 7 & 8410141 & 177.51 & 435069 & 348558 & 150.01 & 144.01 \\
\hline 19 & Wołczyn 8 & 7680074 & 171.4 & 435643 & 349884 & 150.4 & 144.4 \\
\hline 20 & Wołczyn 9 & 7680075 & 176.63 & 436024 & 349856 & 152.83 & 146.83 \\
\hline 21 & Wołczyn 1a & 7680052 & 183.57 & 436292 & 349353 & 150.57 & 144.57 \\
\hline 22 & Wołczyn 2a & 7680110 & 171.25 & 435770 & 350129 & 148.25 & 142.25 \\
\hline
\end{tabular}


Groundwater runoff from the area under study, calculated by hydrological methods and based on daily flows recorded at points closing the Oziąbel and the Wołczyński Strumień river catchments amounted to: $Q_{g}=281.2 \mathrm{dm}^{3} / \mathrm{s}-2.04 \mathrm{dm}^{3} / \mathrm{s} \cdot \mathrm{km}^{2}$ (Wolczyński Strumień) and $Q_{g}=103.8 \mathrm{dm}^{3} / \mathrm{s}-1.03 \mathrm{dm}^{3} / \mathrm{s} \mathrm{km}^{2}$ (Oziąbel).

The contact of river waters with the aquifer is determined by the permeability of river-bed deposits. It varies depending on the character of the river; slow flow usually causes colmatation of the river channel with mineral and organic particles (Woudt and Nicolle [10]). The permeability of the deposits discussed is heavily influenced by the history of river channel evolution and the related buried sediments. Quantitative determination of modelling parameters required performing infiltrometric analyses (Table 2) described by Wassik [8]. The values of vertical hydraulic conductivity $k_{0}$ obtained are given in Table 2 .

Table 2

Measured vertical hydraulic conductivity of river-bed sediments

\begin{tabular}{|c|c|c|c|c|}
\hline No. & Name & $k_{0}[\mathrm{~m} / \mathrm{s}]$ & Name & $k_{0}[\mathrm{~m} / \mathrm{s}]$ \\
\hline 1 & $\mathrm{~K} 1$ & $5.4 \cdot 10^{-4}$ & $\mathrm{~K} 4$ & $1.2 \cdot 10^{-5}$ \\
\hline 2 & $\mathrm{~K} 2$ & $1.1 \cdot 10^{-5}$ & $\mathrm{~K} 5$ & $4.3 \cdot 10^{-5}$ \\
\hline 3 & $\mathrm{~K} 3$ & $3.3 \cdot 10^{-4}$ & $\mathrm{~K} 6$ & $1.8 \cdot 10^{-4}$ \\
\hline
\end{tabular}

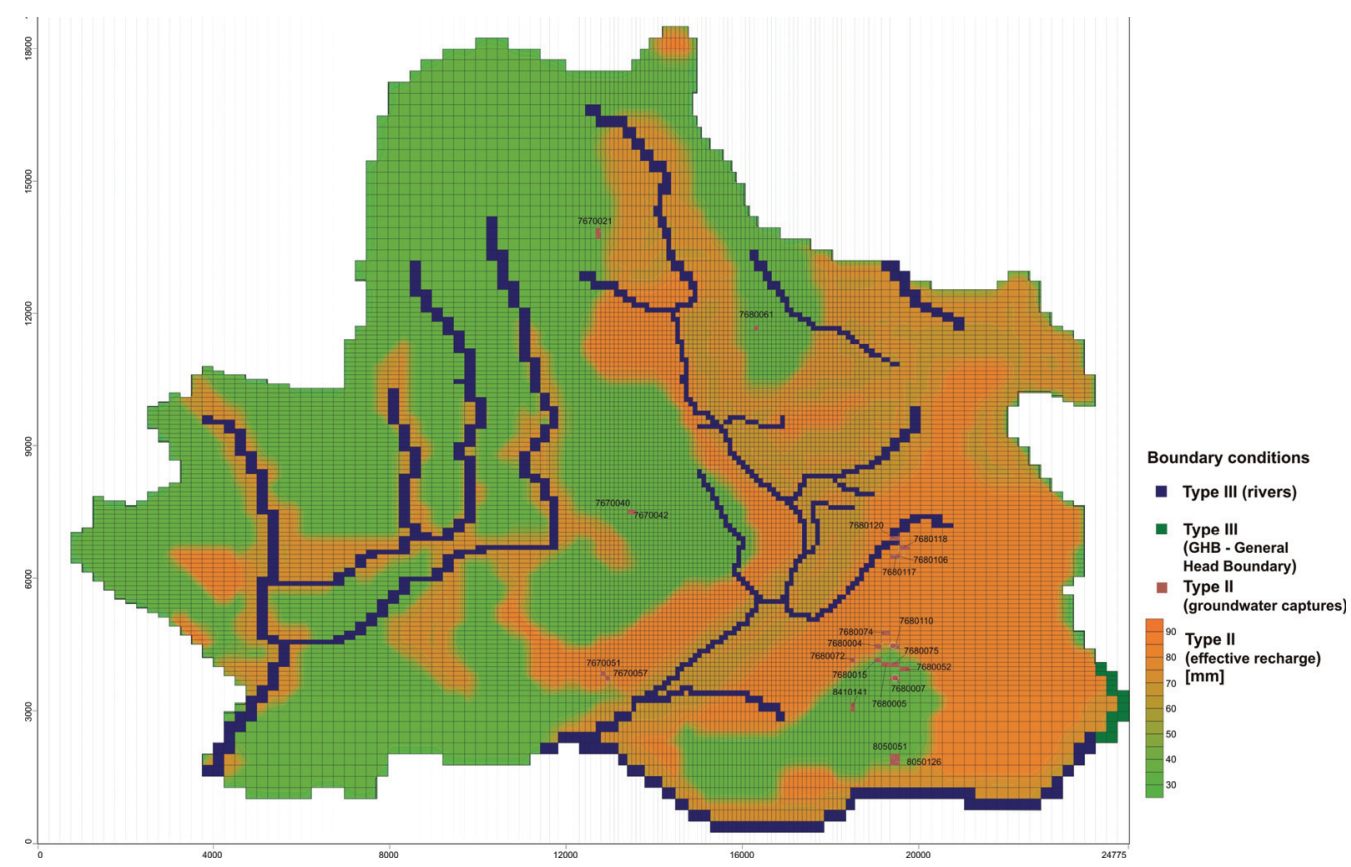

Fig. 4. Boundary conditions used in the model 
The boundaries of the numerical model are identical with those of the system chosen for investigation when devising the conceptual model. The modelled area was divided into three numerical layers. The most shallow and the deepest one simulated quaternary aquifer, the second one from the terrain surface reflected clayey sediments. The area studied was divided by a discretization grid with step $l=250 \mathrm{~m}$. The grid was refined locally in the area with agricultural wastewater use $(l=100 \mathrm{~m})$ to enable precise forecasting of pollutant migration in the future (Fig. 4). In this way, 137 columns and 125 rows were defined (51375 cells in total). Boundary conditions were determined for watersheds (western part of the model) - type 1, watercourses (locally) - type 3, as recharging and groundwater captures - type 2 , and slightly beyond catchment boundaries - type 3 (Fig. 4). Recharge ranged from $30 \mathrm{~mm}$ to $90 \mathrm{~mm}$ per year. The rates of the wells were set as averaged rates from last year $\left(6133 \mathrm{~m}^{3} / \mathrm{d}\right.$ in total). The bottom of the model was considered as impermeable (specified flow $Q=0$ ). The distribution of hydraulic conductivity defined at the conceptual model stage was imported without any additional modifications. The implemented volume parameters (gravity drainage capacity, total porosity, effective porosity) were based on data concerning lithology of waterbearing formations (Fig. 5). Structural surfaces of the terrain and bottoms of cha-

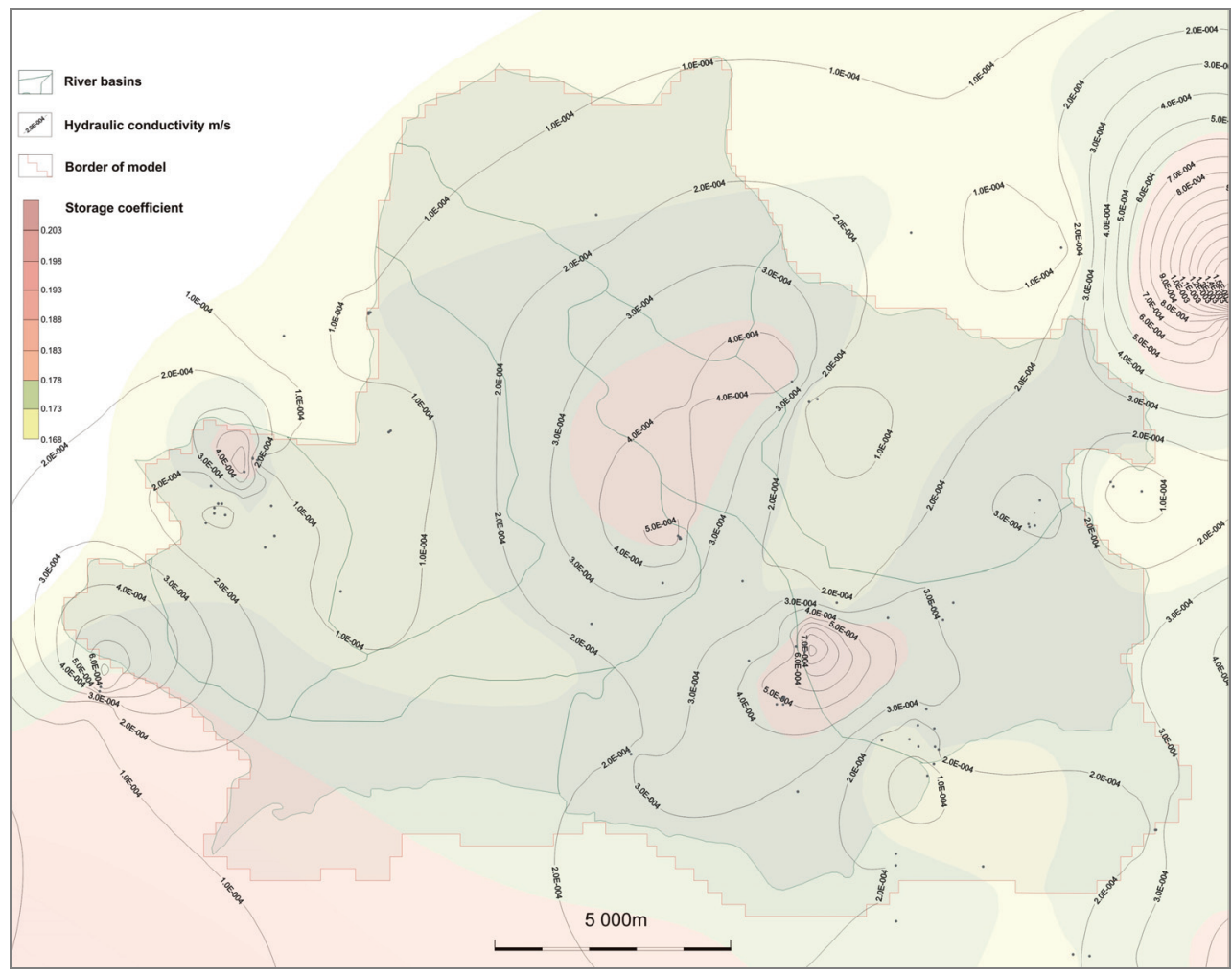

Fig. 5. Distribution of hydraulic conductivity and storativity 
racteristic delimited strata were applied for the model while determining variations in the vertical discretization of the filtration area. The input data to the numerical model were transferred from cross-sections, structural maps of layer bottoms, hydraulic conductivity and storativity maps. All prosperities were distributed from the point data to the area by kriging method in Surfer software. In the light of the above description the model can be classified to the multilayer, quasi $3 \mathrm{D}$ model type.

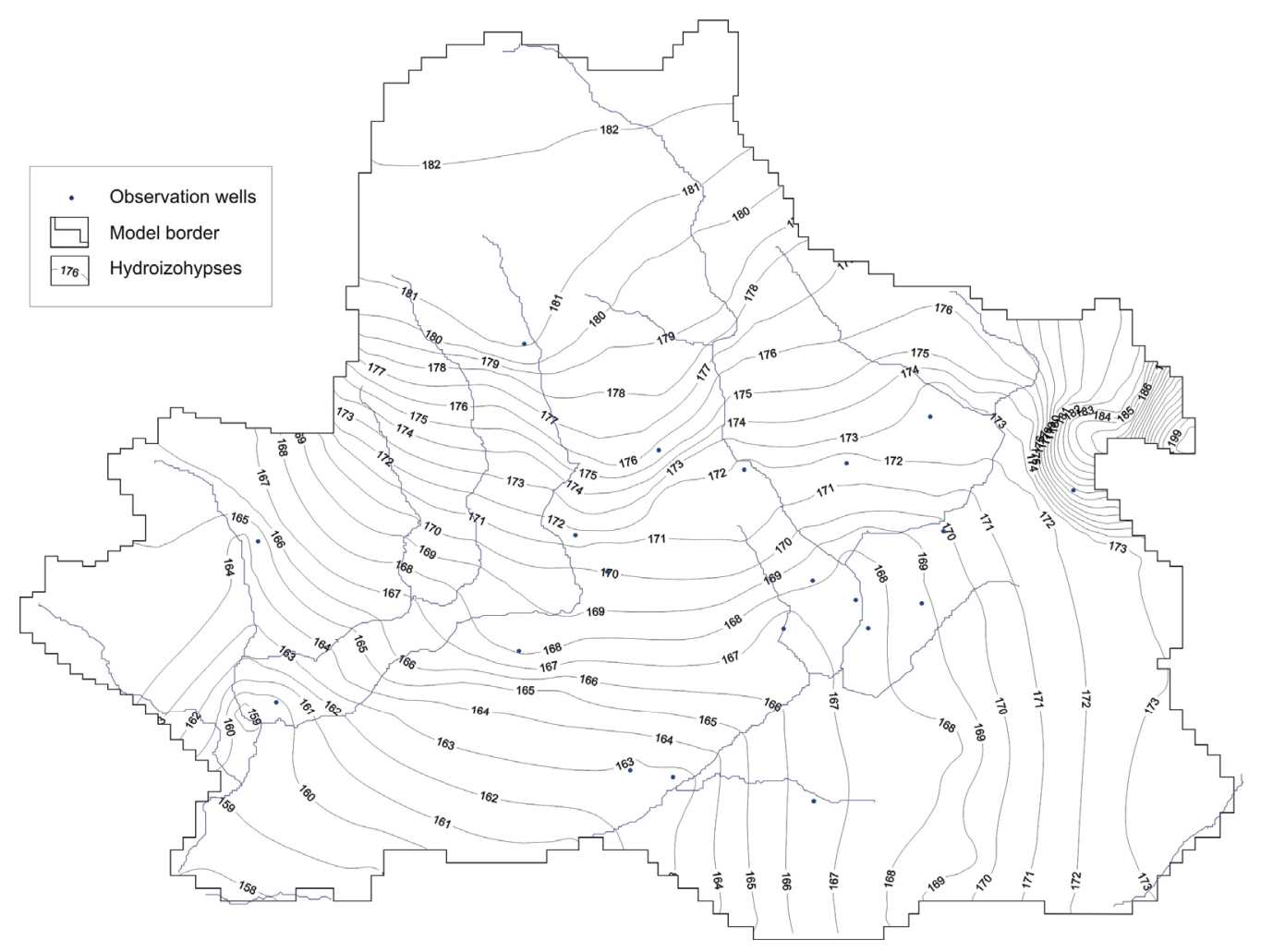

Fig. 6. Groundwater table position in the Neogene aquifer - modelling result

The calibration of the model consisted in modifying its parameters in the way that would enable obtaining the observed groundwater table distribution and runoff parameters. Figure 6 presents groundwater table result distribution with points used during the calibration. Additionally, Fig. 7 depicts a comparison of observed hydraulic heads with those calculated by the model at 21 points - piezometers and dug wells. Good agreement of both values was obtained. The maximum deviation was merely $1.2 \mathrm{~m}$, while the medium value $-0.17 \mathrm{~m}$. 


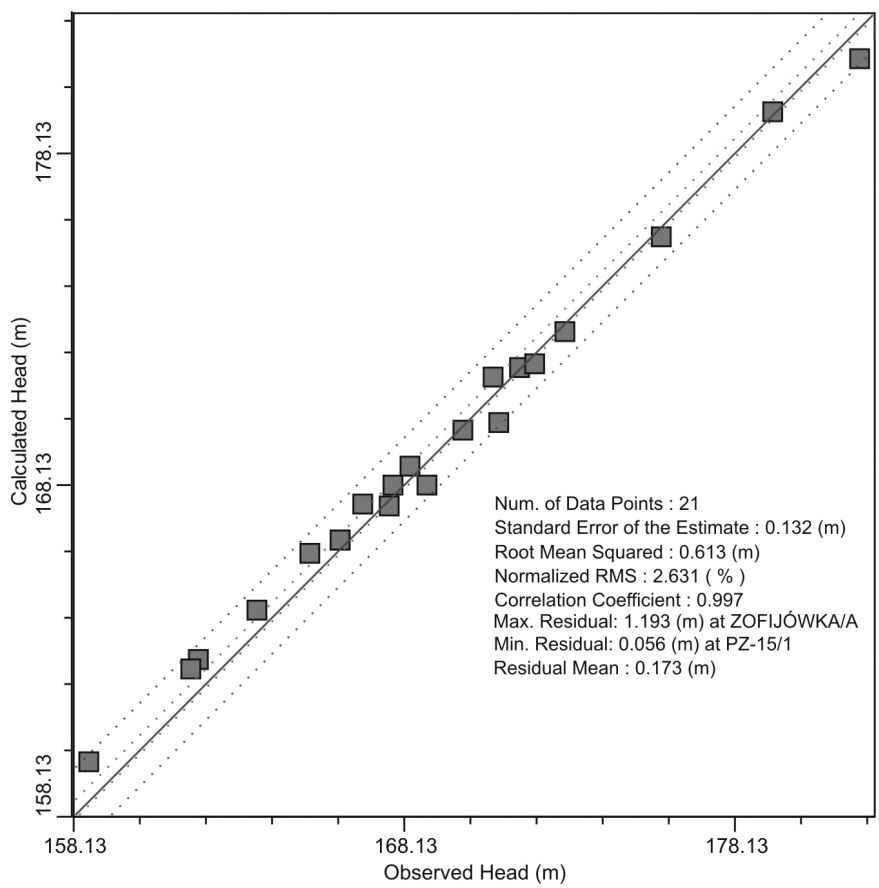

Fig. 7. Comparison of calculated and observed hydraulic head values

The accuracy of the model is also proved by its precisely struck balance (Table 3).

Overall balance of the model

\begin{tabular}{|c|c|c|c|c|}
\hline & \multicolumn{2}{|c|}{ Inflows } & \multicolumn{2}{c|}{ Outflows } \\
\hline & $\mathrm{m}^{3} / \mathrm{d}$ & $\%$ & $\mathrm{~m}^{3} / \mathrm{d}$ & $\%$ \\
\hline Rivers & 3616 & 8 & 39549 & 87 \\
\hline Recharge & 42020 & 92 & - & \\
\hline Lateral flows & 48 & 0 & - & \\
\hline Wells & - & & 6133 & 13 \\
\hline Total & 45684 & 100 & 45682 & 100 \\
\hline Divergence & $-\mathbf{- 1 . 9}$ & $\mathbf{0 . 0 0}$ & & \\
\hline
\end{tabular}

Three basic subareas can be distinguished in the water balance: the Oziąbel river catchment, the Wołczyński Strumien river catchment and the catchment of the Stobrawa river (Fig. 8). 


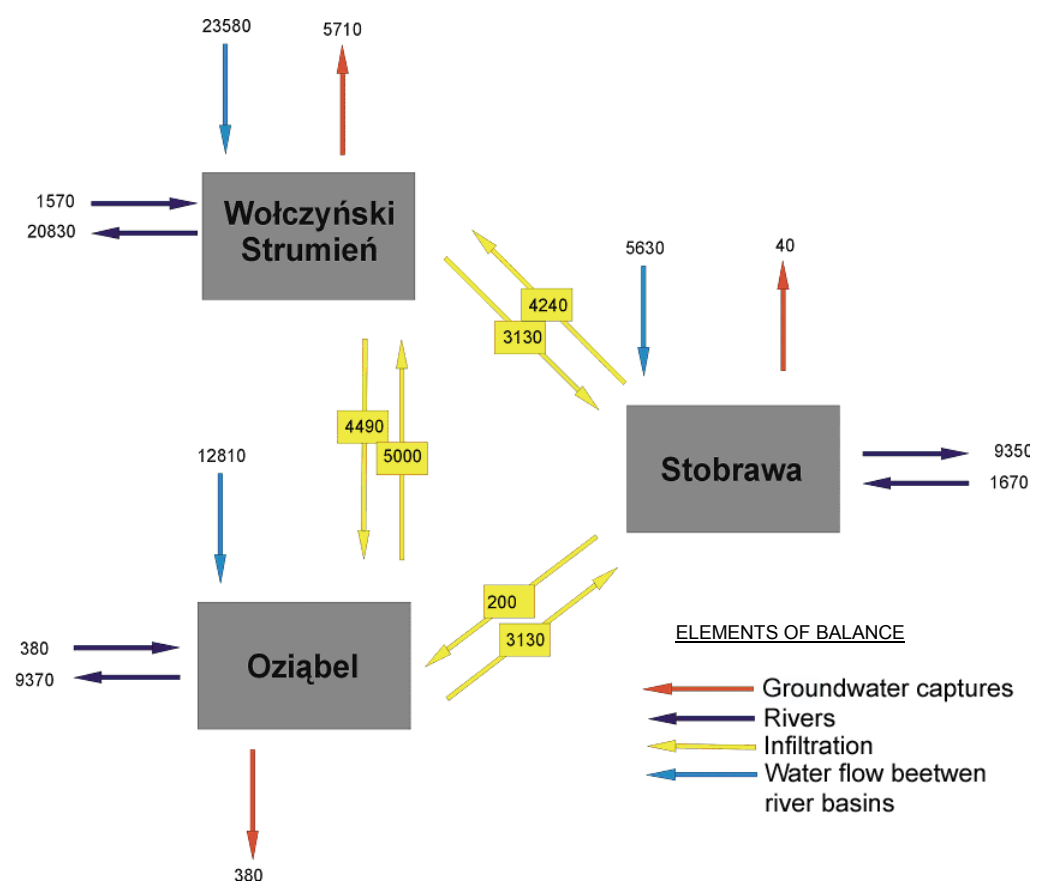

Fig. 8. Water balance of the model

The water balance obtained in the model provides a lot of significant information enabling identification of the elements responsible for shaping groundwater resources and the dynamics of the system (Wang et al. [9]). One should expect divergence from the results obtained with hydrological methods. This divergence informs us about the most important elements of the inflow, not revealed by earlier research. One of such elements is atmospheric recharge, identified with dynamic resources in the model. In hydrological research, dynamic resources were determined from the river catchment runoff. The advantage of modelling methods lies in a possibility of defining these resources more precisely with regard to water exchange between catchments, which is not possible in the case of flow measurements. The results of resource calculations for particular river sub-basins are compiled in Tables 4 and 5.

The main input of the Wołczyński Strumien river catchment balance is its recharge, but total inflows from the Stobrawa and the Oziąbel river catchments provide over $9,000 \mathrm{~m}^{3} / \mathrm{d}$. This proves the flow-through character of the catchment, as over $35 \%$ of the groundwater resources are formed outside its area. As for the Oziąbel, this value has a similar level. In the Stobrawa river catchments, inflows surpass the recharge. These values clearly prove the discrepancies between surface and groundwater catchments. The loading of balance outputs with groundwater captures is strongly varied. The ratio of the total withdrawal to the dynamic re- 
sources varies from a fraction of a percent in the Stobrawa river catchment and 2\% in the Oziąbel river catchment to $24 \%$ in the Wołczyński Strumien river catchment. From the point of view of large-scale resource management, extraction at the given level is fully justified. The anthropogenic impact on the Wołczyński Strumien river basin is slightly stronger than on the remaining areas. Its resources originate mostly from precipitation recharge, moreover extraction is strongly concentrated (groundwater capture in Markotów).

The volumes of renewable resources were defined based on the values of groundwater runoff in profiles closing the catchments of the Wołczyński Strumien and the Oziąbel rivers. The results are shown in Table 4.

Table 4

Runoff characteristics for the Oziąbel and the Wołczyński Strumien river basins between August 2008 and July 2009

\begin{tabular}{|l|l|c|c|c|c|}
\hline \multirow{2}{*}{ River basin } & \multirow{2}{*}{ Characteristic } & \multicolumn{4}{c|}{ Units } \\
\cline { 3 - 6 } & & {$\left[\mathrm{dm}^{3} / \mathrm{s}\right]$} & {$\left[\mathrm{dm}^{3} / \mathrm{s}^{\mathrm{k}} \mathrm{km}^{2}\right]$} & {$[\mathrm{mm}]$} & {$[\%]$} \\
\hline $\begin{array}{l}\text { Oziąbel (Czarna Woda) } \\
{\left[101.1 \mathrm{~km}^{2}\right]}\end{array}$ & Total runoff & 144.8 & 1.43 & 45 & - \\
\cline { 2 - 6 } & Surface runoff & 41.0 & 0.41 & 13 & 28.3 \\
\cline { 2 - 6 } & Groundwater runoff & 103.8 & 1.03 & 32 & 71.7 \\
\hline $\begin{array}{l}\text { Wołczyński Strumień } \\
{\left[137.8 \mathrm{~km}^{2}\right]}\end{array}$ & Total runoff & 335 & 2.44 & 76 & - \\
\cline { 2 - 6 } & Surface runoff & 53.5 & 0.39 & 12 & 15.8 \\
\cline { 2 - 6 } & Groundwater runoff & 281.2 & 2.04 & 64 & 84.2 \\
\hline $\begin{array}{l}\text { Oziąbel + Wołczyński } \\
\text { Strumień } \\
{\left[238.9 \mathrm{~km}^{2}\right]}\end{array}$ & Total runoff & 479.8 & 2.00 & 63 & \\
\cline { 2 - 6 } & Surface runoff & 94.8 & 0.39 & 12 & 19.1 \\
\cline { 2 - 6 } & Groundwater runoff & 385.0 & 1.61 & 51 & 80.9 \\
\hline
\end{tabular}

The value of groundwater runoff ranges from $1.03 \mathrm{dm}^{3} / \mathrm{s} \cdot \mathrm{km}^{2}$ in the Oziąbel river basin to $2.04 \mathrm{dm}^{3} / \mathrm{s} \cdot \mathrm{km}^{2}$ in the Wołczyński Strumien river basin, which produces the renewable resource value of 32 to $64 \mathrm{~mm}$. The average specific groundwater runoff for both catchments is $1.61 \mathrm{dm}^{3} / \mathrm{s} \cdot \mathrm{km}^{2}$, so the renewable resources are equal to $51 \mathrm{~mm}$. The value of specific groundwater discharge is low in both catchments analysed, which proves a low degree of water inflow, hence low renewable resources, according to Jetel and Kullman classification (Kleczkowski [6]).

In order to present the distribution of groundwater resources in particular catchment areas, repeated discharge measurements were performed in sub-basins. Based on them, it was ascertained that discharges of 3.02.2009 are closest to mean groundwater runoff in closing profiles in the year being considered. This finding enabled a conclusion that discharges in river sub-catchments correspond to the mean value of annual groundwater runoff. The results of renewable resource calculations are shown in Table 5. 
Table 5

Groundwater runoff characteristics for the Oziąbel and the Wołczyński Strumień river sub-basins based on hydrological investigations

\begin{tabular}{|c|c|c|c|c|}
\hline $\begin{array}{c}\text { Catchment } \\
\text { No. }\end{array}$ & $\begin{array}{c}\text { Surface } \\
\text { area }\end{array}$ & Discharge & $\begin{array}{l}\text { Runoff } \\
\text { module }\end{array}$ & $\begin{array}{c}\text { Renewable } \\
\text { resources }\end{array}$ \\
\hline & {$\left[\mathrm{km}^{2}\right]$} & {$\left[\mathrm{dm}^{3} / \mathrm{s}\right]$} & {$\left[\mathrm{dm}^{3} / \mathrm{s} \cdot \mathrm{km}^{2}\right]$} & {$[\mathrm{mm}]$} \\
\hline \multicolumn{5}{|c|}{ Wołczyński Strumień } \\
\hline 1 & 27.78 & 2.78 & 0.10 & 3.2 \\
\hline 2 & 37.46 & 75.29 & 2.01 & 63.4 \\
\hline 3 & 40.27 & 134.10 & 3.33 & 105.0 \\
\hline 6 & 32.3 & 66.86 & 2.07 & 65.3 \\
\hline \multicolumn{5}{|c|}{ Oziąbel (Czarna Woda) } \\
\hline 4 & 20.3 & 53.39 & 2.63 & 82.9 \\
\hline 5 & 24.24 & 16.00 & 0.66 & 20.8 \\
\hline 7 & 19.8 & 34.85 & 1.76 & 55.5 \\
\hline 8 & 36.75 & 0.74 & 0.02 & 0.6 \\
\hline
\end{tabular}

\section{MODELLING OUTCOMES ANALYSIS}

Renewable resources in particular river sub-basins vary in a wide range from 0.6 to $105 \mathrm{~mm}$. The lowest values of groundwater renewable resources are recorded in the northern and north-eastern parts of the area under study. They are related to the presence of a thicker zone of clay formations in the geological profile.

Table 6

Dynamic groundwater resources based on modelling results

\begin{tabular}{|c|c|c|c|c|}
\hline & & \multicolumn{3}{|c|}{ Dynamic groundwater resources } \\
\hline $\begin{array}{c}\text { Groundwater balance area } \\
\text { (river sub-basin) }\end{array}$ & $\begin{array}{c}\text { Area } \\
{\left[\mathrm{km}^{2}\right]}\end{array}$ & $\mathrm{m}^{3} / \mathrm{d}$ & $\mathrm{dm}^{3} / \mathrm{s}$ & $\mathrm{dm}^{3} / \mathrm{s} \mathrm{km}^{2}$ \\
\hline 1 & 27.78 & 3630 & 42 & 1.51 \\
\hline 2 & 37.46 & 6966 & 80.6 & 1.79 \\
\hline 3 & 40.27 & 8115 & 93.9 & 2.33 \\
\hline 6 & 32.3 & 4983 & 57.7 & 2.15 \\
\hline Wolczyński Strumień river basin & $\mathbf{1 3 7 . 8 1}$ & $\mathbf{2 3 6 9 4}$ & $\mathbf{2 7 4 . 2}$ & $\mathbf{1 . 9 9}$ \\
\hline 5 & 24.24 & 2974 & 34.4 & 1.42 \\
\hline 8 & 36.75 & 4330 & 50.1 & 1.36 \\
\hline 4 & 20.3 & 2812 & 32.5 & 1.6 \\
\hline 7 & 19.8 & 2752 & 31.9 & 1.61 \\
\hline Oziąbel river basin & $\mathbf{1 0 1 . 0 9}$ & $\mathbf{1 2 8 6 8}$ & $\mathbf{1 4 8 . 9}$ & $\mathbf{1 . 4 7}$ \\
\hline
\end{tabular}


The modelling research provided the water balance of particular catchments and sub-catchments, making it possible to estimate their resources while avoiding the error connected with lateral inflows. Table 6 compares resource sizes in particular catchments. Two high values are noticeable in catchments loaded with spray irrigation (2.33 and $2.15 \mathrm{dm}^{3} / \mathrm{s} \cdot \mathrm{km}^{2}$ ). If resource model values are arranged in ascending order (Fig. 9), one can estimate the minimum amount of waters from spray irrigation permeating to the aquifer system, while eliminating natural factors (natural trend for the area under study). The values recorded for catchments 3 and 6 , diverge from the trend line by $18 \%$ and $14 \%$, respectively, which correspond to the values of infiltration factor of 13 and $9 \mathrm{~mm}$.

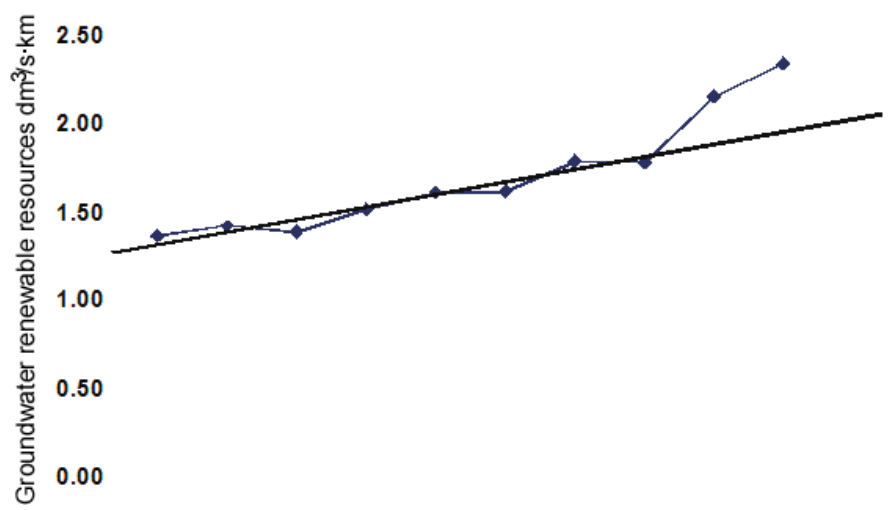

Fig. 9. Variations in groundwater renewable resources module according to modelling research

Compared to the values obtained with hydrological methods, the results have a more uniform character.

\section{SUMMARY}

In order to create a numerical model of hydrogeological conditions, the catchments of the rivers Oziąbel $\left(101.1 \mathrm{~km}^{2}\right)$ and Wołczyński Strumien $\left(137.8 \mathrm{~km}^{2}\right)$, with the total surface area of $238.9 \mathrm{~km}^{2}$ were chosen. The aim of the research was to determine the groundwater dynamics and water balance of the whole area and its river sub-basins. A numerical model was built with the use of Visual ModFlow software Version 3.1.0. The boundaries of the modelled hydrogeological system were established on the watersheds of the Wołczyński Strumień and the Oziąbel rivers, apart from the areas where they run together. The model was extended slightly around the Wołczyński Strumień river catchment to enable a more effective mapping of anthropogenic influ- 
ences on its balance and the hydrodynamic system of the basin, which is related to agricultural use of wastewater. The zone delimited in this way has the surface area $A=271.5 \mathrm{~km}^{2}$. Its hydrological structure consists of one or more rarely two aquifers separated by a pack of Quaternary clays. The model created also enabled obtaining such values of hydrogeological parameters that the model reflected the actual hydraulic head distribution, value of groundwater runoff recorded by surface waters, circulation system and groundwater balance. The agreement obtained allowed considering the model to be appropriate for conducting simulations of balances and groundwater resources, and consequently for protecting them. The water balance of the area discussed is varied. In the western part (the Oziąbel river basin), it is shaped by natural factors. In the eastern part (the Wołczyński Strumień river basin), it is subject to multifactor influence of human activity. The main factor is wastewater spray irrigation for agricultural use, which locally affects the volume of groundwater recharge. The area under study was partitioned by a discretization grid with a step $l=250 \mathrm{~m}$. The grid was condensed locally in the area of agricultural use of wastewater $(l=100 \mathrm{~m})$ to enable precise forecasting of dissolved substance migration in the future. The water balance of the model includes 3 basic subareas: the Oziąbel river catchment, the Wołczyński Strumien river catchment and the catchment of the Stobrawa river. The main positive element of the Wołczyński Strumien river basin balance is recharging, but the inflows from the Stobrawa and the Oziąbel catchments account for the total of $9.000 \mathrm{~m}^{3} / \mathrm{d}$. This proves the flow-through character of the catchment, as over $35 \%$ of its resources are formed outside its area. When it comes to Oziąbel, this value has a comparable level. In the Stobrawa river catchment, inflows surpass the recharge. These values clearly prove the incongruity of surface and groundwater catchments. The Wołczyński Strumień river catchment is subject to slightly higher anthropogenic impact than the remaining areas. Its resources originate mostly in atmospheric recharge, moreover its extraction is strongly concentrated (Markotów groundwater capture).

The modelling research produced the water balances of the whole area under study and river sub-catchments, making it possible to estimate their resources while avoiding the error related to lateral inflows. Generally, the recharge distribution is relatively uniform. Two high values are conspicuous in catchments loaded with spray irrigation. The groundwater renewable resources in particular river sub-basins vary broadly between $0.6 \mathrm{~mm}$ and $105 \mathrm{~mm}$. It is estimated that artificial spray irrigation accounts for $14-18 \%$ of natural infiltration. The lowest values of groundwater renewable resources are recorded in the northern and north-eastern parts of the area under study, which is connected to the occurrence of a thicker zone of clay formations in the geological profile.

Compared to the values obtained with hydrological methods, the presented results have a more homogeneous character. 


\section{REFERENCES}

[1] Anderson M.P., Woessner W.W., Applied Groundwater Modeling, Academic Press, Inc., London 1992.

[2] DąBrowski S., The Prosna valley evolution. The lithology and stratigraphy of Quaternary formations, Wydawnictwo UAM, Poznań 1991, (in Polish).

[3] Dziedziak J., A hydrogeological map of Poland, scale 1:50 000, Rychtal sheet, Wydawnictwo PIG, Warszawa 2000.

[4] GURWIn J., POPRAwSKi L., Assessment of regional groundwater resources by means of numerical modelling methods, [in:] Wspótczesne Problemy Hydrogeologii X, tom 2, Wyd. Sudety, Wrocław 2001 (in Polish).

[5] GóRniK M., A hydrogeological map of Poland, scale 1:50 000, Wołczyn sheet with explanation. Państwowy Instytut Geologiczny, Warszawa 1998 (in Polish).

[6] KleczKowski A.S., Hydrogeology of areas surrounding Poland, Wyd. Geol., Warszawa 1979 (in Polish).

[7] McDonald M.G., Harbaugh A.W., A modular three dimensional finite-difference ground-water flow model, US Geol. Surv. Technical of water resources investigations book 6, chap A1, USGS. Washington, DC, 1988.

[8] WAূSIK M., Infiltration capacity of near-surface formations and groundwater recharging, [in:] Acta Universitatis Wratislaviensis (Hydrogeologia), No 2591, 2003, (in Polish).

[9] WANG H.X., Zhang L., DAwes W.R., LiU C.M., Improving water use efficiency of irrigated crops in the North China Plain - measurements and modelling, Agricultural Water Management, 2001, 48, 151-167.

[10] WoudT van't B.D., Nicolle K., Flow processes below a gravelly riverbed, Journal of Hydrology, 1978, Vol. 17, No. 2, 103-120. 